KEMAS 14 (2) (2018) 247-253
Jurnal Kesehatan Masyarakat

\title{
Analysis Effect of Nutrition Intake on Lung Function of Active Smoker and Non Smoker
}

\author{
Putu Ika Indah Indraswari ${ }^{1 凹}$, Amelia Lorensia $^{2}$, Rivan Virlando Suryadinata ${ }^{3}$ \\ ${ }^{1}$ Program Studi Magister Ilmu Farmasi, Fakultas Farmasi, Universitas Surabaya \\ ${ }^{2}$ Departemen Farmasi-Klinis Komunitas, Fakultas Farmasi, Universitas Surabaya \\ ${ }^{3}$ Departemen Ilmu Kesehatan Masyarakat, Fakultas Kedokteran, Universitas Surabaya
}

\section{Article Info \\ Article History: Submitted July 2018 \\ Accepted August 2018 \\ Published November 2018 \\ Keywords: \\ nutrition intake, \%FVC, $\%$ FEV1, smokers \\ DOI \\ https://doi.org/10.15294/ \\ kemas.v14i2.14947}

\begin{abstract}
Smoking is major cause of respiratory disorders and the data report in 2012 shows in Indonesia there are 384.058 cases of disesase caused by cigarettes. Nicotine and other substance in cigarette smokes are known that will affect nutritional intake and lung function of active smokers. This study observed healthy adult males aged 18-40 who were divided into two groups of active smokers with minimal 2 years exposure to filter type cigarettes and nonsmoker in 2018. Purpose of this study are to analyze the influence of smoking on nutrition intake and lung function and compared the results with nonsmoker groups. Data from 63 respondents in each group showed significant differences in nutrition intake and lung function (\%FVC dan \%FEV1) $(\mathrm{p}=0,001)$ in both groups. Results of this study showed an average caloric intake of 1787,37 calories and decreased the value of $\% \mathrm{FVC}$ and $\% \mathrm{FEV} 1$ respectively $90,48 \%$ and $96,83 \%$ of respondents in the active smokers group. Results of correlation test showed there is a significant relationship between nutritional intake on lung function.
\end{abstract}

\section{Introduction}

Smoking is main cause of lunge disease, from cough to cancer. WHO mentioned that Indonesia is on third rank of largest smoker worldwide under China and India. Based on the data by WHO in 2011, number of smoker in Indonesia was $36.1 \%$ of the population. Most of the smoker start smoking on age 10-18 years old (Kemenkes, 2013). There are sufficient data mentioning cigarette smoke contain complex component reaching 4800 compound variations.

Cigarette smoke flow from mouth to respiration then reach the alveoli. When the smoke flow further to respiratory line, more gas is absorbed and particles are deposited on respiratory line and alveoli. Number of toxic particles and gas inhaled from each cigarette are vary depend on smoke number and volume produced, and lungs characteristic determining number of smoke difused and deposition of toxic particle (Rockville, 2010). This proses will be repeated thus the curing process from damage healing of lungs tissue occure along with defense process by lungs to prevent injury caused by continuous gas inhalation. Lungs of smoker indicate diffusion alteration affecting layer of air line, epithelium and bronchioles (Foronjy \& D’Armiento, 2006).

Nicotine is a component in cigarette able to generate strongest addictive effect and make it difficult to reduce or stop the habit (Rosita 
et al., 2012). Nicotine also causes decrease of meal portion though it does not affect hunger sensation (McGovern \& Benowitz, 2011). To central nerve system, nicotine modulated the line regulating several aspects in meal intake. Regulation of meal habit and metabolism level of brain taken place at hypothalamus, integrating peripheral signal of replete feeling, as well as affects motivation and central emotion (Raatz et al., 2017). The leptin is released from adipose tissue later work centrally to suppress meal intake and increase metabolism level (Tan et al., 2013).

Appropriate nutrition intake is a preventive therapy to prevent the injury of respiratory line such as inflammation, obstructive and deficit of lungs function. Low appetite of smoker causes insufficient nutrition required to maintain lungs health thus increase the risk of COPD (Chronic Obstructive Pulmonary Disease) (Sorli-Aguilar \& MartinLujan, 2016). Malnutrition is condition where deficiency occure, over or unbalance nutrition intake and energy on someone. Over nutrition is when micronutrient and macronutrient intake are over leading to body mass index increase. Under nutrition is when deficiency of energy protein and micronutrient occure (Itoh et al., 2013).

Malnutrition affect structure, elasticity and function of lungs. Malnutrition on patient having pulmonary disease has worse prognosis compare to patient with well nutrition (McKeever et al., 2008). Nutrition intake is associtated with $\mathrm{FEV}_{1}$ (Forced Expiratory Volume in one second) on smoker. The $\mathrm{FEV}_{1}$ value can be seen from lungs function examination by spirometry. The spirometry usage objective is to find out any respiratory disease and help to monitor respond to therapy and direct the decision of further therapy and intervention (Yeh et al., 2008). The research by spirometry will show FVC (Forced Vital Capacity) value and $\mathrm{FEV}$ indicated in litre (L) or \% (Nurjanah et al., 2014).

This research is conducted to find out effect of nutrition intake to lungs function on active smoker and non smoker in Surabaya Selatan by evaluation of individual diet which was 24 hours recall as a questionnaire in estimating kind and frequence of meal and using handheld spirometer to find out lungs function value (Jackson et al., 2008; Shim et al., 2014). Data obtained is used as reference of education regarding nutrition improvement to prevent health problem (Plotnikoff et al., 2015).

\section{Method}

Research conducted is analytic observation research with cross sectional design and pusposive sampling. The research was conducted in Surabaya Selatan from January to March 2018. Total respondents number on two research group are 126 persons. Inclusion criterias are: a. willing to be research subject and fill the agreement letter (informed consent) b. Male respondent ages 18-40 years old (Johns et al., 2014) c. Respondent used minimum has high school education background (Florence, 2017) d. Smoke filtered cigarette $\geq 1$ everyday and has been smoking for at least 2 years (Jain et al., 2009) e. On non smoker group, contains respondents have never smoke or try smoking not more than 100 pcs cigarettes (Sharma \& Ravi, 2010). Exclusion criterias are: a. Subject with concomitant respiratory disease and respiratory obstructive (MacIntyre, 2009) b. Respondent with gastrointestinal disorder (Rizzi et al., 2016), vegetarian or fasting (Stang \& Story, 2005).

This research use interview guidance in form of open question list. Open question used are interview and nutrition intake evaluation by questionnaire to do 24 hours recall thus it can be known kind of food and drink consumed by respondent on both group. The result then processed with Nutrisurvey 2007 application. Based on Permenkes no. 75 year 2013, nutritional adequacy rate for adult male is 2675 calories for age $18-29$ years old and 2725 calories for age 30-40 years old.

The spirometry is used to evaluate lungs function of sample in active smoker and non smoker group. Lungs function evaluation with handheld spirometer (CONTEC ${ }^{\mathrm{rm}}$ SP10) will test the FVC dan $\% F_{E V}$ value. First an audio visual example is presented to the respondent to properly do the measurement procedure. On spirometric measurement, the patient is directed to be relax and breathe in until the chest is full and breathe out as fast and as hard as able (Cheung \& Cheung, 2015). Normal value for $\% \mathrm{FVC}$ is $>75 \%$ and $>80 \%$ for $\% \mathrm{FEV}_{1}$ 
(Antwi et al., 2011) Ethical code approval by Institutional Ethical Committee University of Surabaya (No: 004/KE/XII/2017).

\section{Results and Discussion}

Evaluation of nutrition intake on active and non smoker was conducted by 24 hours recall method. The method was conducted three times to evaluate the nutrition intake on work day and once on the weekend. Based on research by Rothuosen (2012), 24 hours recall method has better performance compare to food report when assesting individual nutrition intake. 24 hours recall is conducted three times since three time measurement can represent individual eating habit for a month (Rankin et al., 2011). Weekend nutrition data taken can indicate macronutrient intake larger than work days (Sun et al., 2010). This research uses male respondent since in Indonesia highest prevalence of smoker is male which is $67 \%$, when respondent selection start from 18 years due to company regulation PP no 109 year 2012, legal age for smoking in Indonesia is 18 years old WHO, 2012). Limit age 40 years old is due to decreased ability of expiration and inspiration of respiratory system, decreased diaphragm strength to $13 \%$ and decreased muscle strength to $20 \%$ on age over 40 years old (Lowery et al., 2013).

Interview result then processed with Nutrisurvey thus obtain the average calorie intake for three days. Comparation between two groups then analyzed with Mann Whitney non parametric statistic test due to abnormal data distribution which was $0,001(\mathrm{p}<0,05)$ when tested using SPSS 23.00 for windows with kolmogrov-smirnov method indicating significant difference $(\mathrm{p}=0,001)$ regarding nutrition intake between active smoker and non smoker. Lack of nutrition intake on active smoker group is caused by nicotine having complex effect to norefinephrine, dopamine, serotonine and $\gamma$-aminobutyric acid by central nerve affects brain in the pretension to eat and metabolism (McGovern \& Benowitz, 2011). Accute respond from this hormone is highly consistant by activating the system to decrease appetite and metabolism (Andresson \& Arner, 2001). Meal habit and nicotine are in same Primary Nerve System PNS line. Meal habit dominantly controlled by interaction between lateral hypothalamus and acumbent nucleus in mesolimbic system and coordination between neotransmitter such as dopamine, serotonine and opioid system (Saper et al., 2002). Nicotine releases dopamine on some brain areas include the "reward" system which are mesolimbic, corpus striatum, frontal cortex and ventral tegmental area (Benowitz, 2010). Meal habit consider as psychological reaction to resist stress on some persons. Nicotine has shown effectiveness in decreasing anxiety then will cover or decrease the willingness to eat, thus when smoke consumption is stopped the anxiety and appetite increase (Picciotto \& Corrigall, 2002).

The research also indicate that number of respondent on active smoker group experienced severe deficiency as many as 39 respondents. This supported the statement by Mineur et.al. (2011) mentioning active smoker will have nutrition intake decrease compare to non smoker. Aligned with Chen et al. (2012) mentioning there is reduction of appetite on active smoker with hoemostatis and reward mechanism. On this research result obtained was only $4 \%$ of active smoker group comply to nutritional adequacy rate (AKG) determined by government. As research by Nayu stating nutrition intake on adult male individu reduced to 240 calories (Ikeda et al., 2016). Other research also mentioned on adult male nutrition requirement deficience is occurred every day (Borg et al., 2015).

Table 1. Characteristics of Respondents

\begin{tabular}{llllllll}
\hline \multirow{2}{*}{ No } & \multirow{2}{*}{ Parameter } & \multirow{2}{*}{ Classification } & \multicolumn{2}{c}{ Active Smoker } & \multicolumn{2}{c}{ Non Smoker } & \multirow{2}{*}{ Homogenity } \\
\cline { 3 - 6 } & & $(\mathrm{n}=126)$ & $\%$ & $(\mathrm{n}=126)$ & $\%$ & \\
\hline \multirow{2}{*}{1.} & \multirow{2}{*}{ Age } & $18-25$ years & 52 & 82,54 & 54 & 85,71 & \\
& & $26-35$ years & 7 & 11,1 & 7 & 11,11 & $\mathrm{P}=0,703$ \\
\hline
\end{tabular}

Source: Primary Data 
Table 2. Amount and Cathegory of Active Smoker Group and Non Smoker Group Nutrition Intake

\begin{tabular}{lllll}
\hline \multirow{2}{*}{$\begin{array}{l}\text { Nutrition Intake } \\
\text { (AKG) }\end{array}$} & \multicolumn{2}{l}{ ACTIVE SMOKER } & \multicolumn{2}{l}{ NON SMOKER } \\
\cline { 2 - 5 } & $\begin{array}{l}\text { Number } \\
\text { (Persons) }\end{array}$ & $\begin{array}{l}\text { Percentage } \\
(\%)\end{array}$ & $\begin{array}{l}\text { Number } \\
\text { (Persons) }\end{array}$ & Percentage (\%) \\
\hline Highly Deficit $(<70 \%)$ & 39 & 61,91 & 10 & 15,87 \\
\hline Medium Deficit $(70-79 \%)$ & 16 & 25,39 & 21 & 33,33 \\
\hline Low Deficit $(80-90 \%)$ & 5 & 7,94 & 23 & 36,51 \\
\hline Normal $(90-120 \%)$ & 3 & 4,76 & 9 & 14,29 \\
\hline Over $(>120 \%)$ & - & - & - & - \\
\hline
\end{tabular}

Source: Primary Data

Table 3. Lungs Function Value of Active Smoker Group and Non Smoker Group Respondent

\begin{tabular}{lllllllll}
\hline \multirow{2}{*}{ Group } & \multicolumn{7}{l}{$\% \mathrm{FVC}$} & \multicolumn{7}{c}{$\% \mathrm{FEV}_{1}$} \\
\cline { 2 - 9 } & $\begin{array}{l}75 \% \% \\
\text { (Persons) }\end{array}$ & $\%$ & $\begin{array}{l}<75 \% \\
\text { (Persons) }\end{array}$ & $\%$ & $\begin{array}{l}>80 \% \\
\text { (Persons) }\end{array}$ & $\%$ & $\begin{array}{l}<80 \% \\
\text { (Persons) }\end{array}$ & $\%$ \\
\hline ACTIVE SMOKER & 7 & 9,52 & 56 & 90,48 & 2 & 3,17 & 61 & 96,83 \\
\hline NON SMOKER & 27 & 42,86 & 36 & 57,14 & 37 & 58,73 & 26 & 41,27 \\
\hline
\end{tabular}

Source: Primary Data

Handheld spirometer usage begin with input the datas of body height and weight, sex, age, and smoking or not smoking on the spirometer. The examination of lungs function was done maximum on $3 \mathrm{pm}$ and during the process respondent would be asked to repeat 3 times and best value was taken (OSHA, 2013). The result indicated that $90.48 \%$ of the respondents in active smoker group have $\% \mathrm{FVC}$ value decrease and $96.83 \%$ have $\% \mathrm{FEV}_{1}$ value decrease while on non smoker group is also found lungs function decrease where $41.27 \%$ of the respondents have $\% \mathrm{FEV}_{1}$ value decrease below $80 \%$.

After compare $\% \mathrm{FVC}$ and $\% \mathrm{FEV}_{1}$ value of both group by Mann Whitney non parametric statistic analysis, due to abnormal data distribution on the values where $\% \mathrm{FVC}(0.001)$ and $\% \mathrm{FEV}_{1}(0.006)$ thus resulting significant difference between the groups regarding the $\% \mathrm{FVC}$ and $\% \mathrm{FEV}$, value. This is aligned with research by Dwarakanath et al. (2014), Helal (2014) and Tantisuwat \& Thaveeratitham (2014) stating there is significant difference of $\% \mathrm{FVC}$ and $\% \mathrm{FEV}_{1}$ value between active smoker group and non smoker group, where the value of lungs function test for active smoker is lower than non smoker.

Smoking cause respiration obstruction and acute change on lungs include alteration in breathing flow resistance, irritation and smoking on early adult individual will affect respiration function. Inhalation of particles contained by smoke increase the lungs function capacity physiological reduction. Each time the smoke is inhaled will make tha active smoker to be exposed by free radical particles which is main source of oxidative stress and inflammation (Sorlí-Aguilar et al., 2015).

The large decrease of \%FVC value on active smoker respondent can be affected by the strength of respiration muscle, where it is affected by smoke free radical on vascular system causing blood supply reduction to respiration muscle affecting lungs function. The reduction of $\% \mathrm{FEV}_{1}$ value on respondent is depended on number of consumption and duration of smoking along the life (minimum 2 years) since the reduction of $\% \mathrm{FEV}_{1}$ value mainly caused by accumulation of cigarette's tobacco consumption (Isabel et al., 2005)

Respiration obstructive disorder caused by genetical or environmental factor. Though smoke exposure said as environmental factor, yet $25-45 \%$ of COPD patient said to not have smoking history. Only 20\% smoker diagnosed of PPOK an around 10\% smoker having The reduction of $\% \mathrm{FEV}_{1}$ value. There for it is said that other than smoke, environmental factor afftecting it which is nutrition intake should be considered in the occurance of Obstructive Pulmonary Disease (Wald et al., 2014). 
By using SPSS with Spearmann method indicate that there is weak yet significant correlation between nutrition intake with respondent's lungs function. The weak relation between both variables can be caused by kind of nutrient in meal intake of respondent able to affect lungs function. From the research result showed that both group samples experienced nutrition intake deficiency as Permenkes no 75 year 2013 standard. The calculation by nutrisurvey application show only $4.76 \%$ of active smoker group respondent and 14.29\% non smoker group respondent comply with AKG requirement. Thus overall $73.81 \%$ of respondents have reduction of $\% \mathrm{FVC}$ value and $76.98 \%$ have reduction of $\% \mathrm{FEV}_{1}$ value

Breathing is an activity of endurance and muscle fibre is part of the body affecting it. On human diaphragm, $75 \%$ or more of the muscle fibre should be on well condition to properly function to maintain respiration endurance. Pump performance is highly important since it will affect the availability and requirement during respiration. Sufficient energy is required to adapt when there was an alteration in ventilator requirement, able to cause pumping malfunction or failure (Schols, 2015).

Due to diaphragm is the most importance muscle in respiration pump, the reduction of the strength is an important clinical sign on an individual since it indicated the occurrence of diaphragm fatigue when the load increase during respiration occurred (Barker et al., 2014). Primary determinant of fatigue is the strength and duration of diaphragm contraction. The strength is indicated with pressure ratio given by diaphragm in one time breath until maximum pressure able to produce by it. When malnutrition decrease the maximum pressure then the ratio of diaphragm pressure in one time breath compare to maximum pressure will increase and the individual tend to has diaphragm fatige causing reduction of lungs function until respiration failure (Jacobs Jr \& Kalhan, 2016). Based on Rabinovich (2004), on individual malnutrition will occure an alteration of respiration muscle function affecting the strength and endurance of lungs function during expiration and inspiration. The decreasing of diaphragm muscle strength will also reduce the respiration vital capacity value, and the weakened of expiration causes the increase of residual volume and the alteration of diaphragm optimum strength then finally reduce the efficiency.

\section{Conclusion}

There is significant difference on nutrition intake $(p=0,001)$ when both research group were compared. The lungs function value which are $\% \mathrm{FVC}$ dan $\% \mathrm{FEV}_{1}$ on active smoker group and non smoker group also indicate significant difference with $\mathrm{p}=0,001$. On correlation test between nutrition intake and lungs function indicate significant relation $(p=0,001)$ between both variables. The limitation of this research is the kind of nutrient unobserved able to affect intake of lungs function value. Maintain normal lungs function can be obtained by improving life habit like stop smoking and proper nutrition intake as advised by daily nutrition adequacy rate (AKG)

\section{Reference}

Andersson, K., \& Arner, P., 2001. Systemic Nicotine Stimulates Human Adipose Tissue Lipolysis through Local Cholinergic and Catecholaminergic Receptors. International Journal of Obesity, 25, pp.1225-1232.

Antwi, D.A., Gbekle, G.E., Cosmos, H.K., Ennin, I.E., Amedonu, E.A., Antwi-Boasiako, C., Clottey, M.K., \& Adzaku, F.K., 2011. Analysis of Lung Function Test at Teaching Hospital. Ghana Medical Journal, 45(4), pp.151-154.

Barker, B.L., McKenna, S., Mistry, V., Pancholi, M., Patel, H., Haldar, K., Barer, M.R., Pavord, I.D., Steiner, M.C., Brightling, C.E., \& Bafadhel, M., 2014. Systemic and Pulmonary Inflammation is Independent of Skeletal Muscle Changes in Patients with Chronic Obstructive Pulmonary Disease. International Journal of COPD, 9, pp.975981.

Benowitz, N., 2010. Nicotine Addiction. N Engl J Med, 362(24), pp.2295-2303.

Borg, S.T., Verlaan, S., Mijnarends, D., Schols, J., de Groot, L., \& Luiking, Y., 2015. Macronutrient Intake and Inadequacies of CommunityDwelling Older Adults, a Systematic Review. Ann Nutr Metab, 66, pp.242-255.

Chen, H., Saad, S., Sandow, S., \& Bertrand, P., 2012. Cigarette Smoking and Brain Regulation of Energy. Frontiers, 3(147), pp.1-8.

Cheung, H., \& Cheung, L., 2015. Coaching Patients during Pulmonary Function Testing: A Practical Guide. Can J Respir Ther, 51(3), pp.65-68. 
Dwarakanath, N., Gandhavalla, V.M., \& Munisekhar, K., 2014. The Correlation of FVC\%, FEV1\%, PEFR Corresponding to Pulmonary Function in Smokers and Non-Smokers. International Journal of Physiotherapy and Research, 2(4), pp.663-666.

Florence, A.G., 2017. Hubungan Pengetahuan Gizi dan Pola Konsumsi dengan Status Gizi Pada Mahasisw TPB Sekolah Bisnis dan Manajemen Institut Teknologi Bandung. Universitas Pasundan Bandung, pp.1-15.

Foronjy, R., \& D'Armiento, J., 2006. The Effect of Cigarette Smoke-derived Oxidants on the Inflammatory Response of the Lung. Clin Appl Immunol Rev, 6(1), pp.53-72.

Helal, F.O., 2014. Impact of Smoking on Adults Lung Age and Ventilatory Function. International Journal of Physiotherapy and Research, 2(2), pp.453-459.

Ikeda, N., Okuda, N., Tsubota-Utsugi, M., \& Nishi, N., 2016. Association of Energy Intake with the Lack of in-Person Review of Household Dietary Records: Analysis of Japan National Health and Nutrition Surveys From 1997 to 2011. J Epidemiol, 26(2), pp.84-91.

Isabel, U., Alberto, C., Marı'a, Q. J., Nerea, M., Xavier, B., \& Jordi, S., 2005. Smoking Habit, Respiratory Symptoms and Lung Function in Young Adults. European Journal of Public Health, 15(2), pp.160-165.

Itoh, M., Tsuji, T., Nemoto, K., Nakamura, H., \& Aoshiba, K., 2013. Undernutrition in Patients with COPD and Its Treatment. Nutrients, 5, pp.1316-1335.

Jackson, K., Byrne, N., Magarey, A., \& Hills, A., 2008. Minimizing Random Error in Dietary Intakes Assessed by 24-H Recall, in Overweight and Obese Adults. European Journal of Clinical Nutrition, 62, pp.537-543.

Jacobs-Jr, D., \& Kalhan, R., 2016. Healthy Diets and Lung Health: Connecting the Dots. AnnalsATS, 13(5), pp.2016.

Jain, A., Agrawal, B., Varma, M., \& Jadhav, A., 2009. Antioxidant Status and Smoking Habits: Relationship with Diet. Singapore Med J, 50(6), pp.64-627.

Johns, D., Walters, J., \& Walters, E., 2014. Diagnosis and Early Detection of COPD Using Spirometry. J Thorac Dis, 6(11), pp.15571569.

Kemenkes., 2013. Perilaku Merokok Masyarakat Indonesia. Jakarta: Pusat Data dan Informasi Kemenkes RI.

Lowery, E., Brubaker, A., Kuhlmann, E., \& Kovacs, E., 2013. The Aging Lung. Clinical Interventions in Aging, 8, pp.1489-1496.
MacIntyre, N., 2009. Spirometry for the Diagnosis and Management of Chronic Obstructive Pulmonary Disease. Respiratory Care, 54(8), pp.1050-1057.

McGovern, A., \& Benowitz., 2011. Cigarette Smoking, Nicotine, and Body Weight. Clin Pharmacol Ther, 9(11), pp.164-168.

McKeever, T., Lewis, S., Cassano, P., Ocke, M., Burney, P., Britton, J., \& Smit, H., 2008. The Relation between Dietary Intake of Individual Fatty Acids, FEV1 and Respiratory Disease in Dutch Adults. Thorax, 63(3), pp.208-214.

Menkes RI., 2013. Peraturan Menteri Kesehatan Republik Indonesia Nomor 75 . Jakarta: Kemenkes RI.

Mineur, Y.S., Abizaid, A., Rao, Y., Salas, R., DiLeone, R.J., Gündisch, D., Diano, S., De-Biasi, M., Horvath, T.L., Gao, X.B., \& Picciotto, M.R., 2011. Nicotine Decreases Food Intake through Activation of POMC Neurons. Science, 332(6035), pp.1330-1332.

Nurjanah., Kresnowati, L., \& Mufid, A., 2014. Gangguan Fungsi Paru dan Kadar Cotinine Pada Urine yang Terpapar Asap Rokok Orang Lain. Kemas, 10(1), pp.43-52.

OSHA., 2013. Spirometry Testing in Occupational Health Programs. Washington: Departement of Labor United State of America.

Picciotto, M., \& Corrigall, W., 2002. Neuronal Systems Underlying Behaviors Related to Nicotine Addiction: Neural Circuits and Molecular Genetics. Journal of Neuroscience, 22(9), pp.3338-3341.

Plotnikoff, R.C., Costigan, S.A., Williams, R.L, Hutchesson, M.J., Kennedy, S.G., Robards, S.L., Allen, J., Collins, C.E., Callister, R., \& Germov, J., 2015. Effectiveness of Interventions Targeting Physical Activity, Nutrition and Healthy Weight for University and College Students: a Systematic Review and Meta-Analysis. International Journal of Behavioral Nutrition, 12(45), pp.1-10.

Raatz, S.K., Jahns, L., Johnson, L.K., Schett, A., Carriquiry, A., Lemeiux, A., Nakajima, M., \& Al'Absi, M., 2017. Smoker Report Lower Intake of Key Nutrients than Nonsmokers, yet Both Fall Short of Meeting Recommended Intakes. Nutr Res, 45, pp.30-37.

Rabinovich, R., Vilaro, J., \& Roca, J., 2004. Evaluation Exercise Tolerance in COPD Patients: the 6-Minute Walking Test. Arch Bronconeumol, 40(2), pp.80-85.

Rankin, D., Ellis, S., MacIntyre, U., Hanekom, S., \& Wright, H., 2011. Dietary Intakes Assessed by 24-H Recalls in Peri-Urban African Adolescents: Validity of Energy 
Intake Compared With Estimated Energy Expenditure. European Journal of Clinical Nutrition, 65, pp.910-919.

Rizzi, M., Mazzuoli, S., Regano, N., Inguaggiato, R., Bianco, M., Leandro, G., Bugianesi, E., Noè, D., Orzes, N., Pallini, P., Petroni, M.L., Testino, G., \& Guglielmi, F.W., 2016. Undernutrition, Risk of Malnutrition and Obesity in Gastroenterological Patients: A Multicenter Study. World J Gastrointest Oncol, 7(563-572), pp.8.

Rockville., 2010. How Tobacco Smoke Causes Diseases. Atlanta: US Departement of Health and Human Services.

Rosita, R., Suswardanya, D. L., \& Abi, Z., 2012. Penentu Keberhasilan Merokok Pada Mahasiswa. Kemas, 8(1), pp.1-9.

Rothuosen, B.W., 2012. Aspects of Energy Intake Assessment, Dietary Intake Patterns and Sleep Duration in Children. Division of Nutrition. Denmark: Technical University of Denmark.

Saper, C., Chou, T., \& Elmquist, J., 2002. The Need to Feed: Homeostatic and Hedonic Control of Eating. Neuron, 36, pp.199-211.

Schols, A., 2015. Nutritional Advances in Patients with Respiratory Disease. Eur Respir Rev, 24, pp.17-22.

Sharma, M., \& Ravi, R., 2010. Visual Effects of Long Term Active Smoking: Are Aircrew Flying NVG-Aided Missions at a Disadvantage? Ind J Aerospace Med, 54(1), pp.18-25.

Shim, J.S., Oh, K., \& Kim, H., 2014. Dietary Assessment Methods in Epidemiologic Studies. Epidemiology and Health, 36, pp. 1-8.

Sorli-Aguilar, M., \& Martin-Lujan, F., 2016. Dietary Patterns are Associated with Lung function among Spanish Smokers without Respiratory Disease. BMC Pulmonary Medicine, 16(162), pp.1-12.

Sorlí-Aguilar, M., Martín-Luján, F., SantigosaAyala, A., Piñol-Moreso, J. L., Flores-Mateo, G., Basora-Gallisà, J., Arija-Val, V., \& Solà-
Alberich, R., 2015. Effects of Mediterranean Diet on Lung Function in Smokers: a Randomised, Parallel and Controlled Protocol. BMC Public Health, 15(74), pp.1-7. Stang, J., \& Story, M., 2005. Nutrition Screening, Assesment, and Intervention. Guidelines for Adolescent Nutrition Services, pp.35-54.

Sun, Y., Roth, D., Ritchie, C., Burgio, K., \& Locher, J., 2010. Reliability and Predictive Validity of Caloric Intake Measures from the 24-Hour Dietary Recalls of Homebound Older Adults. J Am Diet Assoc, 110(5), pp.773-778.

Tan, A., Yen, S., \& Mustapha, F., 2013. The Association between Smoking and Body Mass Index: Results From a National Sample of Malaysian Adults. J Public Health, 21(5), pp.1-10.

Tantisuwat, A., \& Thaveeratitham, P., 2014. Effects of Smoking on Chest Expansion, Lung Function, and Respiratory Muscle Strength of Youths. J. Phys. Ther. Sci., 26, pp.167-170.

Wald, E.F., Borst, B.V., Gosker, H., \& Schols, A., 2014. Dietary Fibre and Fatty Acids in Chronic Obstructive Pulmonary. Respirology, 19, pp.176-184.

WHO., 2012. Global Adult Tobcco Survey: Indonesia Report 2011. World Health Organitation. Jakarta: WHO Regional Office for South East Asia.

Yeh, H.C., Punjabi, N.M., Wang, N.Y., Pankow, J.S., Duncan, B.B., Cox, C.E., Selvin, E., \& Brancati, F.L., 2008. Cross-Sectional and Prospective Study of Lung Function in Adults with Type 2 Diabetes Mellitus: The Atherosclerosis Risk in Communities (ARIC) Study. Diaetes Care, 31(4), pp.741-746. 